What does leadership look like in schools and does it matter for school performance?

Lucy Stokes

Alex Bryson

David Wilkinson

Department of Quantitative Social Science Working Paper No. 19-06

September 2019 


\section{Disclaimer}

Any opinions expressed here are those of the author(s) and not those of the UCL Institute of Education. Research published in this series may include views on policy, but the institute itself takes no institutional policy positions.

DoQSS Workings Papers often represent preliminary work and are circulated to encourage discussion. Citation of such a paper should account for its provisional character. A revised version may be available directly from the author.

Department of Quantitative Social Science, UCL Institute of Education, University College London, 20 Bedford Way, London WC1H OAL, UK 


\title{
What does leadership look like in schools and does it matter for school performance?
}

\author{
Lucy Stokes $^{1}$, Alex Bryson ${ }^{2}$ and David Wilkinson ${ }^{3}$
}

\begin{abstract}
We consider the role played by school leaders in improving pupil attainment, going beyond previous studies by exploring the leadership roles of deputy and assistant heads and classroom-based teachers with additional leadership responsibilities. Using panel data for state-funded secondary schools in England for the period 2010/11-2015/16 we find academy schools typically employ more staff in leadership roles than community schools. Increases in the number of staff in leadership roles below headship level are associated, at least to some extent, with improved school performance in Single Academy Trusts, but this is not the case for schools that are part of Multi Academy Trusts. Our findings suggest that the potential benefits of distributing leadership within schools may only be realised when leaders have sufficient autonomy.
\end{abstract}

JEL Codes: 121

Keywords: school performance; distributed leadership; leadership; school autonomy.

Contact Details: Alex Bryson (a.bryson@ucl.ac.uk), University College London, National Institute of Social and Economic Research and Institute for the Study of Labor

Acknowledgements: We thank the Nuffield Foundation (grant EDU/41926) for funding and the Department for Education for granting access to data from the National Pupil Database and School Workforce Census. We thank Simon Burgess, Francis Green, Jozef Janovsky, Tim Leunig, Olivier Marie, Katherine Williamson and other participants at seminars at the Department for Education, UCL, the University of Maastricht, the 2017 International Workshop on Applied Economics of Education and the project steering committee for comments on an earlier version of the paper. All errors and omissions remain the sole responsibility of the authors.

\footnotetext{
${ }^{1}$ National Institute of Social and Economic Research

${ }^{2}$ University College London, National Institute of Social and Economic Research and Institute for the Study of Labor

${ }^{3}$ University College London and National Institute of Social and Economic Research
} 


\section{INTRODUCTION}

School leadership has been identified as an important policy priority for improving school performance (Pont et al., 2008). Existing studies of school leadership have tended to focus primarily on the role of the headteacher. Much less attention has been paid to the role of deputy and assistant headteachers, and to that of middle leaders (Hallinger and Heck, 1996), where leadership responsibilities are devolved to classroom teachers or other staff within a school. Yet how schools choose to structure their leadership teams may have important consequences for school performance. Harris (2004) states that while there is a considerable amount of literature advocating the benefits of distributed forms of leadership (including the distribution of leadership responsibilities to classroom teachers), there is a lack of evidence as to whether there is a clear relationship with school improvement.

The academisation of schools in England has increased the attention paid to school leadership. The introduction of the academy school system aimed to give school leaders greater freedom to make decisions, for example over staffing, curriculum and other aspects of school organisation, including greater independence from local authority control (Eyles and Machin, 2018). The motivation behind this is that this greater autonomy enables leaders to bring about improvements in school performance (Cirin, 2014). Some have questioned however whether academisation has brought about genuine increases in autonomy for individual schools, particularly for the many academy schools which form part of a Multi Academy Trust. ${ }^{4}$ Evidence from outside of the education sector has indicated that the benefits in devolving leadership responsibilities to lower levels within an organisational hierarchy depend on those who acquire these responsibilities having sufficient autonomy to make decisions (Walton, 1972; Walton, 1985; Lawler, 1986). Given the rapid expansion of the academy system it is

\footnotetext{
${ }^{4}$ See for example: https://schoolsweek.co.uk/the-broken-promise-of-autonomy-for-heads-in-multi-academytrusts/
} 
therefore relevant to ask whether the relationship between distributed leadership and school performance differs according to academy status. Furthermore, given potential differences in autonomy between Single and Multi Academy Trusts, it is also of importance to consider whether there is variation by academy type.

Most empirical studies of the impact of distributed leadership have been small-scale in nature, often based on case studies. In this paper we contribute to the literature on leadership in schools using the School Workforce Census (SWF), a census of all state-funded schools in England and their employees. Our analysis focuses on secondary schools.

Our data (which form a six-year panel) allow us to explore the extent to which teachers who are primarily classroom-based also hold leadership roles, such as Head of Department, as well as the number of deputy and assistant headteachers employed by schools. It is important to consider both forms of leadership (that is, both deputy and assistant heads as well as classroom teachers with additional leadership roles), as schools may opt to substitute responsibilities between these groups; indeed, we explore whether this is the case within our analyses. We consider whether the size of the leadership group is associated with school characteristics, particularly academy status. We link to data on school performance, enabling us to explore the relationship between differing leadership structures and pupil attainment, and whether this differs for academy schools.

The remainder of this paper is structured as follows. Section 2 provides a brief review of the literature on distributed leadership in schools and identifies the hypotheses to be tested in this paper. Section 3 describes our data and approach and Section 4 presents our results. Section 5 concludes. 


\section{LITERATURE AND HYPOTHESES}

There is increasing interest in the role school leadership can play in raising pupil attainment, particularly in the context of reforms to increase school autonomy. The focus of studies of school leadership has typically been the headteacher. For example, in England, Eyles and Machin (2018) find one of the key mechanisms underlying improvements in pupil performance among schools converting to academies is a change in the head teacher at the school. In the US, Ahn and Vigdor (2014) find schools that are forced to change their management and leadership as a result of underperformance go on to improve pupil attainment.

Distributing leadership further down the occupational hierarchy - known as "distributed leadership" - has received less attention. In a review of the existing literature, Bennett et al. (2003) find that the majority of evidence in this area is based on relatively small-scale research, often through case-studies, with limited larger-scale work, and little empirical evidence on the effects of distributed leadership on teaching and learning. More recently, Harris et al. (2019) explore studies conducted since the Bennett et al. (2003) review, and conclude that there remains a lack of robust empirical analysis on this topic. However, some studies have identified the potential for distributed leadership to raise school performance. Harris (2004) provides a review of two studies that have examined the relationship between distributed school leadership and school performance based on in-depth case studies. These showed that a focus on distributing leadership was a common characteristic of effective leadership practice among headteachers (Day et al., 2000) and was also evident in schools that showed improvement despite facing challenging circumstances (Harris and Chapman, 2002). Silns and Munford (2002) also identify improvements in pupil outcomes where leadership roles are distributed. Other studies have suggested that distributed leadership can improve teachers' self-efficacy 
and morale (Mitchell and Sackney, 2000), which may be a potential route through which pupil attainment is improved. More recently, Heck and Hallinger (2009), in a longitudinal study of 195 schools in the US, identify a positive relationship between distributed leadership and improvement in students' attainment in maths. These studies use varying definitions of "distributed" or "middle" leadership. The existing literature acknowledges that there is no precise definition of the term distributed leadership (Bennett et al., 2003; Harris, 2004). This may take many forms, and can happen through informal means as well as in formally defined roles (Spillane et al., 2015). For the purposes of this paper we only consider formally defined roles, which can be identified in our data (described in Section 3 below). We define "middle leaders" as staff who are employed as a classroom teacher but hold additional leadership responsibilities. We define "distributed leadership" more broadly to include not only middle leaders, but also deputy and assistant heads. The School Teachers Pay and Conditions document (Department for Education, 2018) describes deputy and assistant heads as having a major role under the overall direction of the headteacher in: formulating the aims and objectives of the school; establishing the policies through which they are to be achieved; managing staff and resources; monitoring progress towards their achievement; and undertaking any professional duties of the headteacher reasonably delegated by the headteacher.

We begin by exploring the structure of leadership in secondary schools over the period 2010/11 to $2015 / 16$, focusing on the prevalence of middle leaders and deputy and assistant heads. We also explore whether the prevalence of leadership staff varies according to school characteristics. In particular, we consider whether academy schools differ from non-academy schools in terms of the number of staff who hold leadership roles. If academies do have greater freedom over staffing decisions, we may well anticipate that they have chosen to take different decisions from non-academy schools in how they structure leadership. Given their 
independence from local authority control, academy schools may also need to employ more staff with leadership and management responsibilities to compensate for support that would otherwise be provided by the local authority.

We also consider whether schools appear to substitute between middle leaders and deputy and assistant heads. Schools may do so if they have different preferences as to the extent to which they wish to delegate leadership responsibilities to classroom teachers, though it may also reflect the extent to which classroom teachers are willing to undertake such duties.

We then move on to consider whether the number of leadership staff is associated with better school performance, as measured in terms of pupil attainment. Although the studies described above provide some indications of a positive impact of distributing leadership, a priori, it is not clear whether distributed leadership will serve to improve pupil attainment or not. On the one hand, if leadership responsibilities are devolved to the level at which staff are most knowledgeable this may also act to improve school performance. Positive impacts may also operate through giving staff greater voice in decision-making. On the other hand, requirements to spend time on leadership responsibilities may distract staff from their teaching (or other) duties and may potentially reduce morale if staff feel over-stretched by the need to take on additional or multiple tasks. If staff are poorly trained in leadership or have limited management experience, this may also impact on their ability to perform. Therefore the expected direction of any impact on pupil attainment is not necessarily clear. We are only able to explore distributed leadership in terms of the number of individuals observed in these roles; we do not have information on their leadership training or experience. We do however explore whether the number of middle leaders and deputy and assistant heads is associated with Ofsted inspection ratings of the quality of leadership and management in schools. 
Finally, we explore whether any relationship between distributed leadership and school performance differs by academy type and status. If academies genuinely have greater decisionmaking freedom, we anticipate that any potential benefits of distributed leadership are more likely to be apparent in such schools. Given the argument that decision-making freedoms of individual schools are more constrained in Multi Academy Trusts, we also explore whether the relationship between leadership group staff and school performance differs in Multi Academy Trusts, compared with Single Academy Trusts and non-academy schools.

\section{DATA AND APPROACH}

Our data are school-level panel data for the period 2010/11-2015/16 comprising four linked data sets: the School Census, the School Workforce Census, Key Stage 4 attainment data and Ofsted inspection ratings. The School Census is a statutory return, covering all local authority maintained schools, as well as some specific types of non-maintained schools such as academies. It collects information on a range of school and pupil characteristics. Schools are required to complete the School Census three times a year (Autumn, Spring and Summer), with the main collection in the Spring term, which is the data we use in our analysis. The School Census is our starting point for identifying secondary schools in England. We include all schools classified as either a secondary school or middle-deemed secondary school in any year of our analysis period; there are around 3,300 schools in each year on this basis (Table 1).

\section{[TABLE 1 HERE]}

The School Workforce Census (SWF) is a census of all publicly funded schools in England. Again, this includes academy schools. The SWF has been conducted annually since 2010, and 
collects detailed information on the workforce within schools, including contractual details, pay, subjects taught, qualifications and absence. We are able to match in information from the SWF for the vast majority of secondary schools in the School Census (Table 1). We identify deputy and assistant headteachers according to the post in which they are employed. We define middle leaders as those who are employed in a post of classroom teacher ${ }^{5}$, but who are also recorded as having a role as a Head of Department, Head of Year, or Head of House. ${ }^{6}$ Note that our analysis is based on measures of the number of individuals in leadership roles; we do not have information on hours spent on these roles. ${ }^{7}$

Our measures of school performance are drawn from data on school-level attainment at Key Stage 4 (KS4). ${ }^{8}$ We are able to match in data on KS4 attainment for around 90 per cent of schools in each year; the majority of schools for which this was not possible were middledeemed secondary schools, which would generally not include pupils of this age. Our primary performance measure is average total point score at end KS4. Note that our models for this performance measure are based on a five year period (2010/11-2014/15), as this measure is only available for these years. We also construct an alternative performance measure (GCSE points per entry), in order to have a consistent performance measure for all six years (see Wilkinson et al., 2018, for further discussion regarding this measure).

\footnotetext{
${ }^{5}$ We also include those employed in the following posts: Advanced Skills Teachers, Excellent Teachers or Advisory Teachers. Schools have not been able to employ Advanced Skills Teachers or Excellent Teachers from September 2013. A teacher employed as an Advanced Skills Teacher prior to September 2013 may therefore appear in the post of classroom teacher after this date, thus we include them in all years. If we restrict our analysis to classroom teacher posts only, the substantive findings are unchanged.

${ }^{6}$ Teachers may also hold other leadership roles but these are the ones which we are able to identify in the data. We may therefore be understating the extent of middle leadership in schools.

${ }^{7}$ It would be possible to consider the number of deputy and assistant heads in terms of full-time equivalents rather than a headcount measure, but as we are not able to adjust our middle leadership measure on a similar basis we use headcounts for both leadership variables for consistency.

${ }^{8}$ These examinations are taken by pupils at age 16, at the end of compulsory schooling in England (though individuals must remain in either full-time education, an apprenticeship or traineeship, or combine work or volunteering with part-time education until the age of 18 ).
} 
Finally, we also incorporate information on school inspection ratings. The Office for Standards in Education, Children's Services and Skills (Ofsted) are responsible for the inspection of all maintained schools and academies in England. In addition to the overall inspection rating schools are judged on the quality of their leadership and management and quality of teaching. The frequency with which schools are inspected varies; we use information on the school's most recent inspection. ${ }^{9}$

We link the above datasets together using a unique identifier for each school (the variable LAESTAB in our data), which appears in all of the above datasets..$^{10}$

To explore the relationship between leadership and school performance we first estimate the following equation, pooling across years:

$$
\mathrm{Y}_{\mathrm{s}}=\mathrm{X}_{\mathrm{s}} \beta+\operatorname{lm}_{\mathrm{s}} \kappa+1 \mathrm{~d}_{\mathrm{s}} \lambda+\mathrm{A}_{\mathrm{s}} \gamma+\mathrm{Y}_{\mathrm{s}-1}+\mathrm{T}_{\mathrm{t}} \delta+\mathrm{u}_{\mathrm{s}}
$$

where $Y_{s}$ captures average pupil educational attainment in school $s$ as indicated by pupil attainment at Key Stage 4 (using the two alternative attainment measures described above). $Y_{s-l}$ captures the average attainment at Key Stage 2 for the same cohort, when they were aged 11 prior to entering secondary school. This therefore accounts for pupil selection into the secondary school thus providing an added value measure.

\footnotetext{
${ }^{9}$ Given there can be considerable variation in the time since last inspection we additionally control for year of inspection in our models including Ofsted data.

${ }^{10}$ While the different data sources are collected at different points in time throughout the school year, the data are linked together so that all data relate to the same school year. The information collected in the School Census relates to the school year (e.g. 2010/11 is September 2010 to August 2011). This is matched to the School Workforce Census which takes place in November each year (so 2010/11 refers to the November 2010 SWF). This is matched with KS4 attainment data for those pupils completing KS4 in the school year 2010/11.
} 
$X_{s}$ is a vector of pupil observable characteristics in school $s$ namely the number of full-time equivalent pupils at the school, the proportion of pupils eligible for free school meals (FSM), the proportion male, the proportion deemed to have special needs, the proportion White British and the proportion for whom English is an additional language.

$l m_{s}$ and $l d_{s}$ refer to our leadership measures, namely the number of staff who are middle leaders and the number who are deputy and assistant heads respectively. We enter these into our models as separate variables to explore whether different relationships are apparent for these different types of leaders.

$A_{s}$ is a measure of school autonomy, constructed as a $(0,4)$ count variable where schools are scored based on Eyles and Machin's (2018: 38, Table 1) ratings where community and voluntary controlled schools score zero; voluntary aided and foundation schools score 1; academies score 3 and independent schools score 4. Points are scored for each of the following: non-local authority admissions authority (all but Community and Voluntarycontrolled schools); maintained by a non-local authority body (City technology colleges, Academies and independent schools); not obliged to follow the National Curriculum (City technology colleges, Academies and independent schools); fee charging (independent schools). In practice, there are no independent schools in our sample and therefore our autonomy variable ranges from 0 to 3 .

$\mathrm{T}_{\mathrm{t}}$ are time dummies with 2011 (the first year of our analysis period) being the reference category. $\mathrm{u}_{\mathrm{s}}$ is a random error term. Greek letters are parameters to be estimated. 
Our second set of estimates use the panel element of the data to estimate school fixed effects versions of the above model thus:

$\mathrm{y}_{\mathrm{st}}=\mathrm{X}_{\mathrm{st}} \beta+\mathrm{A}_{\mathrm{st}} \gamma+\mathrm{T}_{\mathrm{t}} \delta+\operatorname{lm}_{\mathrm{st}} \kappa+\mathrm{ld}_{\mathrm{st}} \lambda+\mathrm{c}_{\mathrm{s}}+\mathrm{y}_{\mathrm{st}-1}+\mathrm{u}_{\mathrm{st}}$

Here $y_{s t}$ captures pupil attainment in school $s$ at time $t . c_{s}$ are the school-specific unobserved time-invariant constant characteristics. Our panel estimates examine changes in pupil value added within school over time. As such they rely on within-school variance over time for identification. In the case of school autonomy this relies upon schools switching governance structure.

The school fixed effects models can account for fixed unobserved differences between schools that do and do not switch status, thus eliminating this particular source of bias which would affect the OLS estimates where those unobserved variables confound the relationship between investment in leadership and pupil attainment. An example might be the fixed component of management quality. However, we are unable to account for potential endogeneity or to identify in which direction the relationship operates, that is, whether school performance is affected by changes in the number of leaders, or whether the number of leaders changes as a result of school performance. ${ }^{11}$

To establish whether leadership effects on school performance are more apparent in schools with greater autonomy we split the sample in two according to whether they were

\footnotetext{
${ }^{11}$ We do however check for the presence of lags. In our fixed effects models, where KS4 attainment is measured by the total points score, the coefficients on lagged terms for the number of middle leaders, and the number of deputy and assistant heads, are positive, although only statistically significant at the ten per cent level. We also conducted a falsification test by regressing the number of middle leaders on the total points score, and lagged total points score. Here the coefficient on the lagged total points score was not statistically significant. This provides some evidence in support of the proposition that the direction of the effect is from leaders to performance, rather than the other way around.
} 
Academies/Free Schools or not. We also run separate models for Single Academy Trusts and for schools which are part of Multi Academy Trusts.

\section{RESULTS}

Leadership roles in secondary schools

Before presenting our main results we first describe the number of staff in leadership roles in English secondary schools. Table 2 shows the number of staff in secondary schools by post, over the period $2010 / 11$ to $2015 / 16$. The number of headteachers has changed little over this period (perhaps unsurprisingly, given that the total number of secondary schools has also remained relatively stable). However, while fewer than 70 secondary schools had an executive head in 2010/11, this had increased to more than 200 by 2015. As discussed in Lord et al. (2016) however, the SWF may not fully capture the presence of executive headteachers in schools and we do not explore this leadership group in this paper, as our focus is on leadership below headship level. ${ }^{12}$ There has also been some growth in the number of assistant heads, rising from around 12,000 in $2010 / 11$ to approaching 14,000 in $2015 / 16$. Changes in the number of deputy heads and classroom teachers have been more modest, with small declines in both over this period. There has been a similar proportionate decline in the number of middle leaders, such that the percentage of classroom teachers who hold middle leadership roles has remained stable at around 11 per cent throughout this period. ${ }^{13}$

\section{[TABLE 2 HERE]}

\footnotetext{
12 We do however check the sensitivity of our results to the inclusion of a dummy variable for whether the school has an executive head; this has no substantive impact on the magnitude or significance of the coefficients on our leadership variables.

${ }^{13}$ The same applies if we consider the number of middle leaders per pupil, which has remained fairly stable over this period.
} 
Almost all secondary schools have at least one deputy or assistant head (around 98-99 per cent of schools in each year of our analysis), with most schools (more than 80 per cent) having staff in both deputy and assistant head roles. ${ }^{14}$ We noted above that there had been some increase in the overall number of assistant heads over this period; and we also see that there has been some increase in the number of secondary schools employing at least one assistant head; rising from 88 per cent in 2010/11 to 91 per cent in 2015/16 (and at the same time a corresponding decline in the percentage employing at least one deputy head, falling from around 90 per cent to 87 per cent in this period). In addition, the majority of secondary schools have at least some teachers ${ }^{15}$ in middle leadership roles; standing at around 72 per cent in $2015 / 16 .{ }^{16}$

On average secondary schools employed six deputy/assistant headteachers; this had changed little over our analysis period. As noted above, around 11 per cent of classroom teachers in schools held leadership roles; if we consider only schools that have any teachers in these roles, on average around 16 per cent held middle leadership roles. However, there is considerable variation across schools. Figure 1 presents the distribution across schools in 2015/16 for both deputy/assistant headteachers and for middle leaders. The pattern is similar across all years of our analysis period.

Figure 1: Per cent classroom teachers with middle leadership roles, and per cent all teaching staff who are deputy or assistant heads, 2015/16

\footnotetext{
${ }^{14}$ Those secondary schools that do not report having any deputy or assistant heads are typically smaller schools on average.

${ }^{15}$ As discussed in Section 3, we use the term "teachers" to refer to those employed in a post of classroom teacher, as well as those employed in the following posts: Advanced Skills Teachers, Excellent Teacherss, Advisory Teachers or Leading Practitioners.

${ }^{16}$ This is perhaps lower than we might anticipate (given we would expect that most secondary schools would have, for example, at least some Heads of Department) and may therefore raise some concerns over whether such roles are accurately recorded in the data. However, in some schools these leadership roles are held by other staff, particularly deputy or assistant heads.
} 

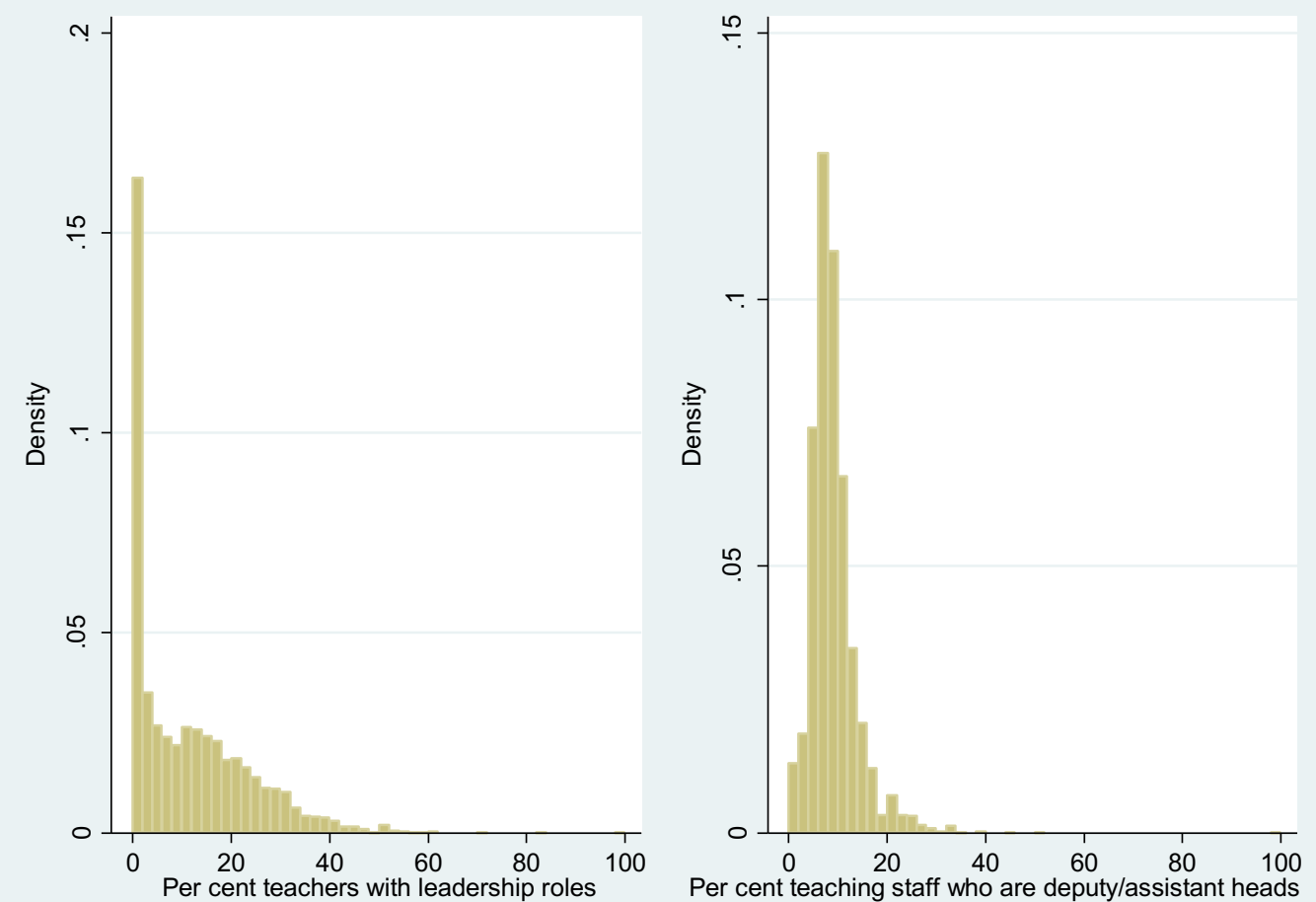
The number of staff in leadership roles is in part a consequence of school size. The left-hand chart in Figure 2 below shows how the average number of middle leaders increases with school size (measured in terms of number of pupils). At the same time, as to be expected, the leadership group typically accounts for a smaller share of staff in larger schools (right-hand chart). Similar patterns are apparent if we consider deputy and assistant heads instead of middle leaders.

Figure 2: Number of middle leaders (and per cent of teachers who are middle leaders), by school size, $2015 / 16$

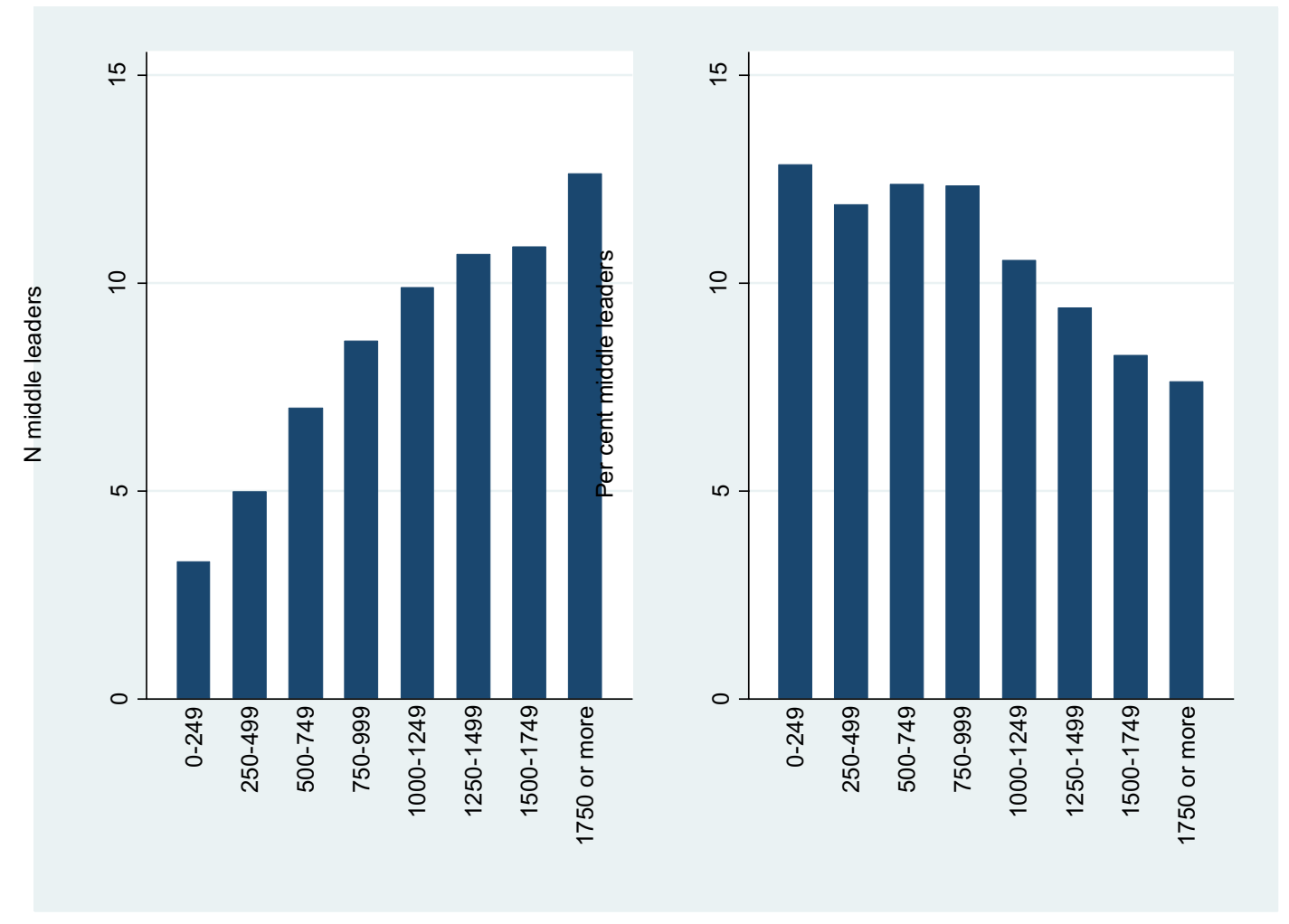

Do academy schools employ more staff in leadership roles?

We hypothesised that academy schools would differ in the number of staff they employ in leadership roles compared with non-academy schools due to their greater freedom over staffing decisions, and potential need for more resources to be dedicated to leadership and management 
when operating with reduced local authority support. This was found to be the case: the first column of Table 3 reports the results of regressing the number of classroom teachers in middle leadership roles on school type, along with a set of other school characteristics, while the second column repeats this for the number of deputy and assistant headteachers. ${ }^{17}$ The results show that academy schools were more likely than community schools to have a greater number of teachers engaged in middle leadership roles, and a higher number of deputy and/or assistant headteachers. However, this was also the case for foundation schools, and in the case of middle leaders, for voluntary aided schools. ${ }^{18}$

Earlier we noted that there has been some debate as to the extent to which schools which are part of Multi Academy Trusts (MATs) actually have the greater autonomy that was a key motivation behind the introduction of the academy system. It is therefore of interest to consider whether there are differences in leadership structures between schools which are part of MATs and schools which are Single Academy Trusts (SATs). We find that both schools that were part of MATs and those that were SATs had a higher number of teachers in middle leadership roles and more deputy and assistant heads compared with community schools (Table 3, final two columns). However, SATs had more middle leaders than schools in MATs, while the reverse applied for the number of deputy and assistant heads. This does therefore point to some differences in the way in which these two types of academy trusts are structuring leadership. ${ }^{19}$

In terms of associations between leadership group size and other school characteristics, unsurprisingly, for both forms of leadership we can see a significant relationship with school

\footnotetext{
${ }^{17}$ We run pooled year regressions but the substantive findings are the same if separate regressions are run for each year. See Table 3 for the full set of characteristics included in the models.

${ }^{18}$ Appendix Table 1 shows the number of schools by type for the schools within our analysis sample.

${ }^{19}$ We also check for differences between converter and sponsor academies (Table 3, middle columns). The number of teachers in middle leadership roles, and the number of deputy and assistant headteachers, were higher for both converter and sponsor academies (with no statistically significant difference between these academy types) compared with community schools.
} 
size, as noted above (Table 3 ). In addition, while the number of middle leaders was lower in schools where a higher proportion of pupils were eligible for free school meals, the reverse was true for the number of staff in deputy/assistant headteacher roles. Overall however, the fairly low R-squared values ${ }^{20}$ indicate that the school level characteristics included in our models appear to explain little of the variation in the size of the leadership group within schools, suggesting other factors are likely to be at play.

\section{[TABLE 3 HERE]}

As academy schools tend to have a higher number of teachers engaged in middle leadership roles, it is of interest to consider if such schools have increased the number of leadership staff on becoming an academy, or whether such schools have always been more likely to structure leadership in this way. Table 4 presents the results of fixed effects models which indicate that an increase in school autonomy (which effectively captures those schools converting to academy status) is indeed associated with increases in the number of middle leaders and the number of deputy and assistant heads. The magnitude of these effects is however fairly small, with a one point increase in autonomy associated with an increase of 0.17 middle leaders. Nevertheless, this suggests that in addition to the changes in head teacher leadership that Eyles and Machin (2018) have shown to result from academisation, there are also changes in other forms of leadership associated with becoming an academy. This may reflect greater freedom for academies over staffing choices; it may also reflect a need for academies to devote more resources to leadership and management to undertake activities that may have previously been provided through local authority support. The results also show the decline in the number of middle leaders over the period covered by our analysis, as well as the rise in the number of

\footnotetext{
${ }^{20}$ See Table 3: 0.06 for the model for middle leaders and 0.29 for the model for deputy and assistant heads
} 
deputy and assistant heads (driven by the increase in assistant heads), as shown in the descriptive statistics presented in Table 2 and discussed above.

Do schools substitute between middle leaders and deputy/assistant heads?

If we additionally control for the number of staff who are deputy or assistant heads, we find that the number of teachers in middle leadership roles is lower in schools where there are more deputy/assistant heads (final column, Table 4). So this may be indicative of some element of substitution between a larger narrow leadership group and devolving aspects of leadership to classroom teachers. This may reflect different preferences among schools in the extent to which they favour distributing leadership responsibilities to classroom teachers, or the extent to which teachers are willing or able to take on such roles. It may also be influenced by financial considerations (classroom teachers are likely to receive additional payments for taking on such additional responsibilities, while average salaries of deputy and assistant heads will be higher than those of classroom teachers).

\section{[TABLE 4 HERE]}

Is leadership group size associated with school inspection ratings?

Our measures of the number of middle leaders and the number of deputy and assistant heads provide information about the quantity of leadership, but it may well be leadership quality, rather than quantity per se, that matters for school performance. We do not have information in our data on the quality of middle leadership in schools. We can however, consider whether leadership group size is associated with higher inspection ratings for the quality of leadership and management in the school. Arguably, this is important to establish before exploring whether our quantity measures of leadership show a relationship with school performance. Table 5 presents the results of ordered probit regressions where the dependent variable is the 
Ofsted rating for quality of leadership and management (coded such that a higher score reflects a higher quality rating). We also report models for inspection ratings for the quality of teaching and overall effectiveness of the school. For each quality measure, the first column shows the results of models which simply regress each Ofsted rating on our two measures of leadership, while the second column includes controls for school characteristics (see note to Table 5 for full details). This indicates a positive and statistically significant association between the number of middle leaders and each quality rating, which remains significant, although smaller in magnitude, once controlling for other school characteristics, for both quality of leadership and management and quality of teaching, although not for overall effectiveness. The number of deputy and assistant heads in a school only remains borderline statistically significant for the quality of leadership and management; it is not associated with either quality of teaching or overall effectiveness once accounting for the same set of school characteristics. This seems largely driven by the inclusion of a variable for school size (number of pupils); having a higher ratio of deputy and assistant heads to pupils is therefore not associated with ratings for quality of teaching or overall effectiveness, but is to some extent associated with ratings for quality of leadership. Overall however, it is important to note that these effects are small. Table 6 shows the predicted probabilities for the quality of leadership and management rating, based on the model including controls for school characteristics. The left-hand panel shows the predicted probability of being in each Ofsted category when the number of middle leaders increases from 7 (the mean value observed in our sample) to 8 , holding all other variables in the model at their mean values. Similarly, the right-hand panel shows the effect of increasing the number of deputy and assistant heads from 6 to 7 (with 6 being the mean in our sample). Overall, this shows little effect on the predicted probabilities, thus while there is a statistically significant association, it is quantitatively small. Nevertheless, the fact that we observe some positive 
correlation between our measure of the number of middle leaders and the quality of leadership in the school provides motivation for exploring the role of middle leaders further. ${ }^{21}$

\section{[TABLES 5 AND 6 HERE]}

Is leadership group size associated with better school performance?

Table 7 presents the results of estimating equation 1 described above. In the left-hand panel the dependent variable is the average total point score and the models cover the period 2010/112014/15. Both the number of middle leaders and the number of deputy/assistant heads show a positive and significant association with school performance, when controlling solely for prior performance at KS2 and a set of year dummies (column 1). These relationships remain statistically significant when additionally controlling for autonomy (column 2) and for additional school characteristics in terms of school type, school size and pupil composition (column 3). While these relationships are statistically significant, they are small in magnitude: an additional middle leader is associated with a 0.07 higher total points score, while an additional deputy or assistant head is associated with a 0.53 higher total points score (the average total points score in our sample over this period stands at 334 points). A similar picture is apparent when considering performance in terms of GCSE points per entry, for which we have data for an additional year, so that our sample here covers 2010/11 to 2015/16 (right-hand panel of Table 7). However once the full set of controls are included the relationship between the number of deputy and assistant heads and this measure of school performance is no longer statistically significant.

\footnotetext{
${ }^{21}$ We also experimented with alternative specifications including an interaction term for the two leadership measures, however, the interaction term was not statistically significant.
} 
Earlier, we stated that we would anticipate that any potential benefits from distributing leadership would be greater where schools had more autonomy. As one means of exploring this we check for the presence of interactions between our leadership variables and autonomy (fourth and eighth columns of Table 7). For both school performance measures, there is a positive interaction between autonomy and middle leadership, such that the effect of increasing the size of the middle leadership group on performance increases as autonomy rises. In contrast, there is a negative sign on the interaction term for autonomy and deputy/assistant head leadership, suggesting the effect of increasing the number of deputy and assistant heads on school performance reduces as autonomy increases (though at all levels of autonomy, there is still a positive effect on performance associated with an increase in the number of deputy and assistant heads).

\section{[TABLE 7 HERE]}

The models presented above do not take account of fixed unobservable traits of schools. Tables 8 and 9 present the results of estimating fixed effects models for each performance measure (that is, estimating the model set out in equation 2 earlier). For the total points score (Table 8), when we consider all schools (column 1), the number of middle leaders is positively and (statistically) significantly associated with school performance, but the number of deputy and assistant heads is not statistically significant. As for our OLS models, we also explore adding in interactions between autonomy and our leadership variables (column 2). This indicates a positive interaction between autonomy and the number of middle leaders, but a negative interaction between autonomy and the number of deputy/assistant heads. As our autonomy variable does not just capture a move to academy status, to further explore differences on this basis, we also estimate separate models specifically for academy and non-academy schools 
(columns 3 and 4). Here the academy group can include not only schools which are academies throughout our analysis period, but also those which become academies during this period, while non-academy schools are those which never become academies in this timeframe. The findings for non-academy schools are similar to those for all schools. In contrast, the fixed effects models for academies show no statistically significant association between the leadership variables and performance. The final two columns present the results of separate models for MATs and SATs (here we only include schools once they have already converted to academy status). The results point to quite different findings for the two types of academies. In schools which are part of MATs, neither leadership variable shows a statistically significant association with performance as measured by the total points score. In SATs however, both leadership group variables are positively and significantly associated with school performance. If we consider performance in terms of GCSE points per entry (Table 9), for non-academies, we see a positive and statistically significant coefficient for the number of deputy and assistant heads, with no statistically significant relationship for the number of middle leaders. Again differences are apparent between MATs and SATs, with a statistically significant association with the number of deputy and assistant heads for SATs, but not for schools which are part of MATs. On the basis of this performance measure however, there is no significant association with the number of middle leaders.

This variation according to the attainment measure used is perhaps surprising. The differences are not driven by the inclusion of the additional year in the models for GCSE points per entry; if we restrict our models to the same time period for both measures, the findings are substantively the same. One possible explanation may be changes to the total points score over this period, which are not evident in the points per entry measure, brought about in part due to the exclusion of many non-GCSE qualifications from headline measures of attainment following the Wolf Review. This led schools to switch towards GCSE qualifications, with this 
change mainly affecting low attainment pupils that would previously have been less likely to sit GCSEs. These changes have affected the total points score over our analysis period, but have had much less impact on the points per entry measure (see Wilkinson et al., 2018, for further details of the changes to qualifications over time).

\section{[TABLES 8 AND 9 HERE]}

\section{DISCUSSION AND CONCLUSIONS}

Studies of school leadership often focus on the role of the headteacher. In this paper, we use administrative data on the school workforce to explore the role of other leaders within schools - both deputy and assistant heads, and classroom teachers who take on additional leadership roles (middle leaders).

Leadership group size is partly a function of school size, but also varies with other school characteristics. We find academy schools tend to employ more middle leaders and more deputy and assistant heads compared with community schools. Furthermore, we find that academisation is associated with an increase in the number of middle leaders and deputy/assistant heads; suggesting that the effects of academisation on leadership are not solely confined to headteachers, as demonstrated in previous studies, but extend beyond that. We find some evidence of substitution between deputy/assistant headteachers and employing teachers in middle leadership roles: schools with more deputy and assistant heads had fewer middle leaders.

Our leadership measures only provide an indicator of the quantity, rather than the quality, of leadership. Larger leadership groups, at least in terms of middle leaders, were however 
associated with higher inspection ratings for the quality of leadership and management, although this relationship was small in magnitude.

Once we account for fixed unobserved characteristics of schools, we find a positive (though not large) association between the number of leaders below headship level and school performance in non-academy schools, and in SATs, but not in schools which form part of MATs. We see some differences depending on the metric of school performance used: when considering performance in terms of total points score we see a statistically significant association with the number of middle leaders, but if we consider performance in terms of GCSE points per entry, we instead see an association with the number of deputy and assistant heads. Further research would be required in order to understand more about the reasons as to why results might differ by performance measure, but it is not uncommon for studies of school performance to show variation according to the performance metric used (see, for example, Wilkinson et al., 2018). As noted above, one potential explanation may relate to the changes in the types of qualifications counted following the Wolf Review, which had some impact on the total points score but not on the points per entry measure.

However, regardless of the performance measure used, the results point to some differences between SATs and MATs in the relationship between leadership structures and performance. SATs also tended to have more middle leaders than MATs, but fewer deputy and assistant heads, though both types of academy, on average, employed more of both types of leader than non-academy schools. It has been argued that schools which are part of MATs have fewer decision-making freedoms, indeed fewer than non-academy schools. In light of this, our findings suggest benefits from distributing leadership may only be apparent when schools and their staff have sufficient autonomy in order to bring about change. 
Although our analyses indicate some statistically significant associations between leadership group size and performance, even after controlling for fixed unobserved characteristics of schools, the relationships are fairly small in magnitude. Our analyses only take account of the size of the leadership group, and not its quality (although we have information on Ofsted judgements as to the quality of leadership and management in the school, we cannot necessarily infer that this relates to quality of leadership below headship level); if we were able to capture the quality of middle leadership we may well expect to see greater effects. There are a number of other limitations of our analysis, for example, there may well be leadership roles, both formal and informal, that are not identified within our data. It would also be valuable to know how much time staff allocate to their different roles, to be able to unpick any potential trade-off between time spent on leadership activities versus time focused on teaching. How schools choose to structure their leadership teams will also have financial implications for schools, such that school leaders and governing boards will need to weigh up the most effective means of using resources to maximise the benefits of leadership for school performance. Nevertheless, our findings suggest that understanding more about leadership structures and the contribution of leaders below headship level may help shed further light on how school performance may be improved. Our findings also point to the importance of schools, and their staff, having genuine autonomy if distributing leadership is to bring about benefits for pupil attainment. 


\section{References}

Ahn, T. and Vigdor, J. (2014) "The Impact of No Child Left Behind's Accountability Sanctions on School Performance: Regression Discontinuity Evidence from North Carolina", NBER Working Paper No. 20511.

Bennett, N., Harvey, J.A., Wise, C. and Woods, P.A. (2003) 'Distributed Leadership: A Review of Literature', National College for School Leadership.

Cirin, R. (2014) "Do academies make use of their autonomy?", Department for Education Research Report RR366

Day, C., Harris, A., Hadfield, M., Tolley, H. and Beresford, J. (2000) Leading Schools in Times of Change. Milton Keynes: Open University Press.

Department for Education (2018) School teachers' pay and conditions document 2018 and guidance on school teachers' pay and conditions, Department for Education, September 2018.

Eyles, A., and Machin, S. (2018) 'The Introduction of Academy Schools to England's Education', Journal of the European Economic Association, jvy021, https://doi.org/10.1093/jeea/jvy02

Hallinger, P. and Heck, R. (1996) 'Reassessing the Principal's Role in School Effectiveness: A Critical Review of Empirical Research 1980-1995', Educational Administration Quarterly 32(1): 4-5.

Harris, A. (2004) “Distributed Leadership and School Improvement. Leading or Misleading?”, Educational Management Administration \& Leadership, 32(1), 11-24.

Harris, A. and Chapman, C. (2002) Effective Leadership in Schools Facing Challenging Circumstances: Final Report. Nottingham: NCSL. 
Heck, R. and Hallinger, P. (2009) Assessing the contribution of distributed leadership to school improvement and growth in math achievement. American Educational Research Journal, 46, 626-658.

Lawler, E. E. (1986) High Involvement Management, San Francisco: Jossey-Bass

Lord, P., Wespieser, K., Harland, J., Fellows, T. and Theobald, K. (2016). Executive Head Teachers: What's in a Name? A Full Report of the Findings. Slough, Birmingham and London: NFER, NGA and TFLT.

Mitchell, C. and Sackney, L. (2000) Profound Improvement: Building Capacity for a Learning Community. Lisse: Swets \& Zeitlinger.

Pont, B., Nusche, D. and Moorman, H. (2008) Improving school leadership, Volume 1: Policy and Practice, OECD, Paris: OECD.

Silns, H. and Mulford, B. (2003) 'Leadership and School Results', International Handbook of Educational Administration. Dordrecht: Kluwer.

Spillane, J. Harris, A. and Jones, M. (2015) Novice School Principals: Opportunities and Challenges for taking a Distributed Perspective on School Leadership, British Educational Research Journal 41:61:1068-1085.

Walton R. E. (1972) “How to counter alienation in the plant”, Harvard Business Review 50, 6: $70-81$

Walton, R. E. (1985) "From commitment to control in the workplace", Harvard Business Review, 63, 2: 77-84

Wilkinson, D., Bryson, A. and Stokes, L. (2018) "Assessing the variance in pupil attainment: how important is the school attended?", National Institute Economic Review, No. 243, R4-R16. 
Table 1 Analysis sample

\begin{tabular}{|l|c|c|c|c|c|c|}
\hline & $2010 / 11$ & $2011 / 12$ & $2012 / 13$ & $2013 / 14$ & $2014 / 15$ & $2015 / 16$ \\
\hline School Census & 3,327 & 3,283 & 3,303 & 3,356 & 3,397 & 3,414 \\
\hline & & & & & & \\
\hline $\begin{array}{l}\text { School Workforce } \\
\text { Census }\end{array}$ & 3,230 & 3,152 & 3,232 & 3,287 & 3,348 & 3,362 \\
\hline & $(97.1 \%)$ & $(96.0 \%)$ & $(97.9 \%)$ & $(97.9 \%)$ & $(98.6 \%)$ & $(98.5 \%)$ \\
\hline & & & & & & \\
\hline KS4 attainment & 2,965 & 2,927 & 3,018 & 3,078 & 3,155 & 3,189 \\
\hline & $(89.1 \%)$ & $(89.2 \%)$ & $(91.4 \%)$ & $(91.7 \%)$ & $(92.9 \%)$ & $(93.4 \%)$ \\
\hline
\end{tabular}

Note: Figures in parentheses are number of schools as \% of all secondary schools in the School Census

Table 2 Number of staff in school leadership roles, secondary schools, 2010/11-2015/16

\begin{tabular}{|l|c|c|c|c|c|c|}
\hline & $2010 / 11$ & $2011 / 12$ & $2012 / 13$ & $2013 / 14$ & $2014 / 15$ & $2015 / 16$ \\
\hline & & & & & & \\
\hline Headteachers & 3,273 & 3,131 & 3,224 & 3,292 & 3,326 & 3,307 \\
\hline $\begin{array}{l}\text { Executive } \\
\text { headteachers }\end{array}$ & 68 & 93 & 110 & 150 & 185 & 219 \\
\hline Deputy headteachers & 5,607 & 5,327 & 5,392 & 5,391 & 5,492 & 5,448 \\
\hline $\begin{array}{l}\text { Assistant } \\
\text { headteachers }\end{array}$ & 11,999 & 11,686 & 12,322 & 12,705 & 13,575 & 13,766 \\
\hline Classroom teachers & 207,482 & 201,327 & 205,584 & 204,163 & 203,978 & 201,112 \\
\hline $\begin{array}{l}\text { Classroom teachers } \\
\text { with leadership roles }\end{array}$ & 21,825 & 21,735 & 21,738 & 21,516 & 21,607 & 21,216 \\
\hline
\end{tabular}

Note: We use the term "classroom teachers" to refer to all teachers who are not headteachers or in deputy or assistant headteacher posts. Thus here a classroom teacher also includes those who are employed as Advanced Skills Teachers, Excellent Teachers, Advisory Teachers or Leading Practitioners. 
Table 3: School characteristics associated with leadership group size (middle leaders and deputy/assistant headteachers), OLS

\begin{tabular}{|c|c|c|c|c|c|c|}
\hline & \multicolumn{2}{|c|}{ (1) All academy types combined } & \multicolumn{2}{|c|}{$\begin{array}{c}\text { (2) Distinguishing between } \\
\text { converter and sponsored } \\
\text { academies }\end{array}$} & \multicolumn{2}{|c|}{$\begin{array}{c}\text { (3) Distinguishing between MATs } \\
\text { and SATs }\end{array}$} \\
\hline & Middle leaders & $\begin{array}{c}\text { Deputy and } \\
\text { assistant heads }\end{array}$ & Middle leaders & $\begin{array}{c}\text { Deputy and } \\
\text { assistant heads }\end{array}$ & Middle leaders & $\begin{array}{c}\text { Deputy and } \\
\text { assistant heads }\end{array}$ \\
\hline \multicolumn{7}{|c|}{ School type (ref: community schools) } \\
\hline \multirow[t]{2}{*}{ Academy (including free schools) } & $1.978 * * *$ & $0.334 * * *$ & & & & \\
\hline & $(7.313)$ & $(3.792)$ & & & & \\
\hline \multirow[t]{2}{*}{...Converter academy } & & & $2.158 * * *$ & $0.330 * * *$ & & \\
\hline & & & $(7.115)$ & $(3.729)$ & & \\
\hline \multirow[t]{2}{*}{...Sponsored academy } & & & $1.909 * * *$ & $0.473 * * *$ & & \\
\hline & & & $(5.155)$ & $(3.036)$ & & \\
\hline \multirow[t]{2}{*}{...Multi Academy Trust } & & & & & $1.702^{* * *}$ & $0.496 * * *$ \\
\hline & & & & & $(5.443)$ & $(4.800)$ \\
\hline \multirow[t]{2}{*}{...Single Academy Trust } & & & & & $2.545^{* * *}$ & $0.219 *$ \\
\hline & & & & & $(7.532)$ & $(1.918)$ \\
\hline \multirow[t]{2}{*}{...Free school } & & & $-1.024^{*}$ & $-1.042 * * *$ & $-0.996 *$ & $-1.052 * * *$ \\
\hline & & & $(-1.870)$ & $(-5.343)$ & $(-1.828)$ & $(-5.395)$ \\
\hline \multirow[t]{2}{*}{ Foundation } & $0.916 * * *$ & $0.190 *$ & $0.925 * * *$ & $0.194 *$ & $0.925^{* * *}$ & $0.194 *$ \\
\hline & $(2.678)$ & $(1.834)$ & $(2.704)$ & $(1.873)$ & $(2.704)$ & $(1.872)$ \\
\hline \multirow[t]{2}{*}{ Voluntary aided } & $1.027^{* * *}$ & 0.007 & $0.974 * * *$ & -0.025 & $0.989 * * *$ & -0.028 \\
\hline & $(2.734)$ & $(0.073)$ & $(2.588)$ & $(-0.257)$ & $(2.629)$ & $(-0.289)$ \\
\hline \multirow[t]{2}{*}{ Voluntary controlled } & $1.897^{*}$ & -0.279 & $1.953^{*}$ & -0.269 & $1.958^{*}$ & -0.268 \\
\hline & $(1.687)$ & $(-1.060)$ & $(1.730)$ & $(-1.031)$ & $(1.735)$ & $(-1.025)$ \\
\hline \multirow[t]{2}{*}{ Other } & -0.743 & $-0.537 * * *$ & -1.068 & $-0.681^{* * *}$ & -1.047 & $-0.688 * * *$ \\
\hline & $(-1.025)$ & $(-2.616)$ & $(-1.421)$ & $(-3.263)$ & $(-1.396)$ & $(-3.296)$ \\
\hline \multicolumn{7}{|l|}{ Pupil characteristics } \\
\hline $\mathrm{N}$ pupils & $0.004^{* * *}$ & $0.004 * * *$ & $0.003 * * *$ & $0.004 * * *$ & $0.003 * * *$ & $0.004^{* * *}$ \\
\hline
\end{tabular}




\begin{tabular}{|c|c|c|c|c|c|c|}
\hline & $(9.966)$ & (34.273) & $(8.475)$ & $(31.332)$ & $(8.644)$ & (31.499) \\
\hline \multirow[t]{2}{*}{$\% \mathrm{FSM}$} & $-0.028 * *$ & $0.062 * * *$ & $-0.028 * *$ & $0.059 * * *$ & $-0.025^{* *}$ & $0.059 * * *$ \\
\hline & $(-2.536)$ & $(13.784)$ & $(-2.372)$ & $(13.731)$ & $(-2.253)$ & $(12.651)$ \\
\hline \multirow[t]{2}{*}{$\%$ male } & -0.003 & $0.003 *$ & -0.002 & $0.003 *$ & -0.002 & $0.003 *$ \\
\hline & $(-0.421)$ & $(1.760)$ & $(-0.303)$ & $(1.950)$ & $(-0.284)$ & $(1.927)$ \\
\hline \multirow[t]{2}{*}{$\%$ White British } & $-0.029 * * *$ & -0.005 & $-0.034 * * *$ & $-0.007^{* *}$ & $-0.033^{* * *}$ & $-0.007^{* *}$ \\
\hline & $(-3.232)$ & $(-1.394)$ & $(-3.800)$ & $(-2.171)$ & $(-3.685)$ & $(-2.279)$ \\
\hline \multirow[t]{2}{*}{$\% \mathrm{EAL}$} & -0.014 & 0.001 & -0.021 & -0.002 & -0.020 & -0.002 \\
\hline & $(-1.115)$ & $(0.125)$ & $(-1.596)$ & $(-0.352)$ & $(-1.561)$ & $(-0.422)$ \\
\hline \multirow[t]{2}{*}{$\%$ SEN } & -0.044 & 0.003 & -0.045 & 0.004 & -0.045 & 0.003 \\
\hline & $(-1.570)$ & $(0.214)$ & $(-1.586)$ & $(0.242)$ & $(-1.583)$ & $(0.217)$ \\
\hline \multicolumn{7}{|l|}{ Year } \\
\hline \multirow[t]{2}{*}{2012} & $-0.386 * * *$ & $-0.137 * * *$ & $-0.429 * * *$ & $-0.141^{* * *}$ & $-0.439 * * *$ & $-0.141 * * *$ \\
\hline & $(-3.964)$ & $(-3.491)$ & $(-4.217)$ & $(-3.557)$ & $(-4.411)$ & $(-3.569)$ \\
\hline \multirow[t]{2}{*}{2013} & $-0.635 * * *$ & $-0.089 *$ & $-0.672 * * *$ & $-0.083^{*}$ & $-0.680 * * *$ & $-0.085^{*}$ \\
\hline & $(-4.831)$ & $(-1.771)$ & $(-4.899)$ & $(-1.668)$ & $(-5.098)$ & $(-1.701)$ \\
\hline \multirow[t]{2}{*}{2014} & $-0.967 * * *$ & 0.053 & $-0.987^{* * *}$ & 0.064 & $-0.983 * * *$ & 0.058 \\
\hline & $(-6.273)$ & $(0.922)$ & $(-6.221)$ & $(1.122)$ & $(-6.351)$ & $(1.006)$ \\
\hline \multirow[t]{2}{*}{2015} & $-1.116^{* * *}$ & $0.490 * * *$ & $-1.108 * * *$ & $0.501 * * *$ & $-1.092^{* * *}$ & $0.494^{* * *}$ \\
\hline & $(-6.270)$ & $(7.434)$ & $(-6.208)$ & (7.661) & $(-6.157)$ & (7.529) \\
\hline \multirow[t]{2}{*}{2016} & $-1.407 * * *$ & $0.422^{* * *}$ & $-1.402 * * *$ & $0.436 * * *$ & $-1.382^{* * *}$ & $0.427^{* * *}$ \\
\hline & $(-7.602)$ & $(6.147)$ & $(-7.570)$ & (6.395) & $(-7.483)$ & $(6.242)$ \\
\hline \multirow[t]{2}{*}{ Constant } & $5.802^{* * *}$ & $0.675^{* *}$ & $6.602 * * *$ & $1.048^{* * *}$ & $6.451 * * *$ & $1.097^{* * *}$ \\
\hline & $(5.662)$ & $(1.974)$ & $(6.130)$ & $(2.960)$ & $(5.983)$ & $(3.087)$ \\
\hline R-squared & 0.063 & 0.291 & 0.066 & 0.294 & 0.067 & 0.295 \\
\hline $\mathrm{N}$ & 18,324 & 18,324 & 18,324 & 18,324 & 18,324 & 18,324 \\
\hline
\end{tabular}

Notes: t-statistics in parentheses. $* \mathrm{p}<0.10 ; * * \mathrm{p}<0.05 * * * \mathrm{p}<0.01$.

Models also include dummy variable with value equal to 1 where any of the listed pupil characteristics are missing. 
Table 4: School characteristics associated with leadership group size, fixed effects

\begin{tabular}{|c|c|c|c|}
\hline & \multicolumn{2}{|c|}{ (1) } & \multirow{2}{*}{\begin{tabular}{|c|} 
(2) \\
Middle leaders \\
\end{tabular}} \\
\hline & Middle leaders & $\begin{array}{c}\text { Deputy and } \\
\text { assistant heads }\end{array}$ & \\
\hline \multirow[t]{2}{*}{ Autonomy } & $0.167^{* * *}$ & $0.056^{* * *}$ & $0.178^{* * *}$ \\
\hline & $(3.691)$ & $(2.591)$ & $(3.970)$ \\
\hline \multirow[t]{2}{*}{$\mathrm{N}$ deputy and assistant heads } & & & $-0.211 * * *$ \\
\hline & & & $(-12.249)$ \\
\hline \multicolumn{4}{|l|}{ Pupil characteristics } \\
\hline \multirow[t]{2}{*}{$\mathrm{N}$ pupils } & $0.003 * * *$ & $0.004 * * *$ & $0.004 * * *$ \\
\hline & $(8.066)$ & $(20.154)$ & $(10.006)$ \\
\hline \multirow[t]{2}{*}{$\%$ FSM } & $0.033^{* * *}$ & -0.001 & $0.033 * * *$ \\
\hline & $(3.353)$ & $(-0.244)$ & $(3.346)$ \\
\hline \multirow[t]{2}{*}{$\%$ male } & $-0.028 * *$ & $-0.014 * *$ & $-0.031 * *$ \\
\hline & $(-2.210)$ & $(-2.241)$ & $(-2.448)$ \\
\hline \multirow[t]{2}{*}{$\%$ White British } & 0.008 & $-0.013 * * *$ & 0.005 \\
\hline & $(1.112)$ & $(-3.885)$ & $(0.725)$ \\
\hline \multirow[t]{2}{*}{$\% \mathrm{EAL}$} & -0.001 & -0.001 & -0.002 \\
\hline & $(-0.135)$ & $(-0.286)$ & $(-0.165)$ \\
\hline \multirow[t]{2}{*}{$\%$ SEN } & 0.001 & 0.002 & 0.001 \\
\hline & $(0.027)$ & $(0.123)$ & $(0.039)$ \\
\hline \multicolumn{4}{|l|}{ Year } \\
\hline \multirow[t]{2}{*}{2012} & -0.105 & $-0.137 * * *$ & -0.134 \\
\hline & $(-1.115)$ & $(-3.046)$ & $(-1.428)$ \\
\hline \multirow[t]{2}{*}{2013} & $-0.239 * *$ & -0.029 & $-0.245^{* *}$ \\
\hline & $(-2.415)$ & $(-0.624)$ & $(-2.490)$ \\
\hline \multirow[t]{2}{*}{2014} & $-0.354 * * *$ & 0.093* & $-0.334 * * *$ \\
\hline & $(-3.430)$ & $(1.885)$ & $(-3.256)$ \\
\hline \multirow[t]{2}{*}{2015} & $-0.260 * *$ & $0.351^{* * *}$ & $-0.186^{*}$ \\
\hline & $(-2.318)$ & $(6.565)$ & $(-1.664)$ \\
\hline \multirow[t]{2}{*}{2016} & $-0.519 * * *$ & $0.405^{* * *}$ & $-0.433 * * *$ \\
\hline & $(-4.659)$ & $(7.635)$ & $(-3.903)$ \\
\hline \multirow[t]{2}{*}{ Constant } & $4.293 * * *$ & $3.739 * * *$ & $5.083 * * *$ \\
\hline & $(5.764)$ & $(10.544)$ & $(6.833)$ \\
\hline R-squared & 0.009 & 0.046 & 0.019 \\
\hline $\mathrm{N}$ & 18,324 & 18,324 & 18,324 \\
\hline
\end{tabular}

Notes: t-statistics in parentheses. ${ }^{*} \mathrm{p}<0.10 ; * * \mathrm{p}<0.05 * * * \mathrm{p}<0.01$.

Models also include dummy variable with value equal to 1 where any of the listed pupil characteristics are missing. 
Table 5 Ofsted ratings, regression results (ordered probit)

\begin{tabular}{|l|c|c|c|c|c|c|}
\hline & \multicolumn{2}{|c|}{$\begin{array}{c}\text { Quality of leadership and } \\
\text { management }\end{array}$} & \multicolumn{2}{c|}{ Quality of teaching } & \multicolumn{2}{c|}{ Overall effectiveness } \\
\hline & Raw & Controls & Raw & Controls & Raw & Controls \\
\hline N middle leaders & $0.017^{* * *}$ & $0.005^{* *}$ & $0.017^{* * *}$ & $0.004^{* *}$ & $0.017^{* * *}$ & 0.003 \\
\hline & $(8.051)$ & $(2.290)$ & $(8.011)$ & $(2.068)$ & $(8.141)$ & $(1.470)$ \\
\hline N deputy/assistant heads & $0.033^{* * *}$ & $0.011^{*}$ & $0.027^{* * *}$ & 0.007 & $0.027^{* * *}$ & 0.004 \\
\hline & $(6.227)$ & $(1.926)$ & $(5.303)$ & $(1.315)$ & $(5.244)$ & $(0.715)$ \\
\hline & & & & & & \\
\hline N & 17,498 & 17,498 & 17,498 & 17,498 & 17,498 & 17,498 \\
\hline
\end{tabular}

Notes: $\mathrm{z}$-statistics in parentheses. ${ }^{*} \mathrm{p}<0.10 ; * * \mathrm{p}<0.05 * * * \mathrm{p}<0.01$

Controls: school type (Academy; Community (reference category); Foundation school; Voluntary Aided; Voluntary Controlled; Other); number of pupils in school; \% pupils eligible for FSM; \% pupils with English as an additional language; $\%$ pupils with special educational needs; $\%$ male pupils; $\%$ pupils who are White British; dummy variable where any of pupil characteristics variables are missing; year; year of most recent inspection.

Table 6 Predicted probabilities, quality of leadership and management rating

\begin{tabular}{|l|l|l|l|l|}
\hline & $\begin{array}{l}\text { N middle } \\
\text { leaders }=7\end{array}$ & $\begin{array}{l}\text { N middle } \\
\text { leaders }=8\end{array}$ & $\begin{array}{l}\text { N } \\
\text { deputy/assistant } \\
\text { heads=6 }\end{array}$ & $\begin{array}{l}\text { N } \\
\text { deputy/assistant } \\
\text { heads=7 }\end{array}$ \\
\hline Outstanding & 0.2538 & 0.2553 & 0.2545 & 0.2580 \\
\hline Good & 0.5933 & 0.5930 & 0.5932 & 0.5922 \\
\hline $\begin{array}{l}\text { Satisfactory/requires } \\
\text { improvement }\end{array}$ & 0.1389 & 0.1380 & 0.1385 & 0.1363 \\
\hline Inadequate & 0.0139 & 0.0137 & 0.0138 & 0.0135 \\
\hline & & & & \\
\hline
\end{tabular}

Notes: predicted probabilities derived from ordered probit model for quality of leadership and management shown in column 2 of Table 5 above, holding values of all other variables at their mean. 
Table 7 KS4 attainment: total points score and GCSE points per entry, regression results (pooled OLS)

\begin{tabular}{|c|c|c|c|c|c|c|c|c|}
\hline & \multicolumn{4}{|c|}{$\begin{array}{c}\text { Total average points score } \\
(2011-2015)\end{array}$} & \multicolumn{4}{|c|}{$\begin{array}{l}\text { GCSE points score per entry } \\
(2011-2016)\end{array}$} \\
\hline & Raw & $\begin{array}{l}\text { Including } \\
\text { autonomy }\end{array}$ & $\begin{array}{l}\text { Including } \\
\text { controls }\end{array}$ & $\begin{array}{l}\text { Including } \\
\text { interaction } \\
\text { terms }\end{array}$ & Raw & $\begin{array}{l}\text { Including } \\
\text { autonomy }\end{array}$ & $\begin{array}{l}\text { Including } \\
\text { controls }\end{array}$ & $\begin{array}{c}\text { Including } \\
\text { interaction } \\
\text { terms }\end{array}$ \\
\hline \multirow[t]{2}{*}{$\mathrm{N}$ middle leaders } & $0.186 * * *$ & $0.151^{* * *}$ & $0.074 * *$ & -0.015 & $0.021 * * *$ & $0.019 * * *$ & $0.009 * * *$ & 0.002 \\
\hline & (5.384) & (4.451) & (2.435) & $(-0.323)$ & (4.918) & (4.484) & (2.777) & $(0.368)$ \\
\hline \multirow[t]{2}{*}{$\begin{array}{l}\mathrm{N} \text { deputy/assistant } \\
\text { heads }\end{array}$} & $0.922 * * *$ & $0.839 * * *$ & $0.530 * * *$ & $0.718 * * *$ & $0.048 * * *$ & $0.043 * * *$ & 0.003 & 0.025 \\
\hline & $(9.723)$ & $(8.880)$ & $(5.472)$ & (4.561) & (4.359) & (3.940) & $(0.269)$ & (1.579) \\
\hline \multirow[t]{2}{*}{ Autonomy } & & $1.923^{* * *}$ & $2.022 * * *$ & $2.233^{* * *}$ & & $0.096 * * *$ & $0.117^{* * *}$ & $0.152 * * *$ \\
\hline & & (8.629) & $(9.904)$ & $(4.728)$ & & (3.751) & $(5.426)$ & (3.18) \\
\hline \multirow[t]{2}{*}{$\begin{array}{l}\text { Autonomy*middle } \\
\text { leaders }\end{array}$} & & & & $0.056 * *$ & & & & $0.005^{*}$ \\
\hline & & & & $(2.505)$ & & & & $(1.925)$ \\
\hline \multirow[t]{2}{*}{$\begin{array}{l}\text { Autonomy*deputy/ } \\
\text { assistant heads }\end{array}$} & & & & $-0.103 *$ & & & & $-0.011 *$ \\
\hline & & & & $(-1.660)$ & & & & $(-1.828)$ \\
\hline R-squared & 0.680 & 0.684 & 0.715 & 0.715 & 0.764 & 0.764 & 0.818 & 0.819 \\
\hline $\mathrm{N}$ & 14,786 & 14,786 & 14,786 & 14,786 & 17,841 & 17,841 & 17,841 & 17,841 \\
\hline
\end{tabular}

Notes: t-statistics in parentheses. * $\mathrm{p}<0.10 ; * * \mathrm{p}<0.05 * * * \mathrm{p}<0.01$

All models additionally control for prior average attainment at KS2 as well as including a set of year dummies. The additional controls included in the third and seventh columns are: number of pupils in school; \% pupils eligible for FSM; \% pupils with English as an additional language; \% pupils with special educational needs; \% male pupils; \% pupils who are White British; dummy variable where any of pupil characteristics variables are missing. The fourth and eighth columns additionally include interactions between autonomy and leadership. 
Table 8 KS4 total points score, 2011-2015, regression results (fixed effects)

\begin{tabular}{|c|c|c|c|c|c|c|}
\hline & All & $\begin{array}{l}\text { All (plus } \\
\text { interaction) }\end{array}$ & Non-academies & $\begin{array}{l}\text { Academies } \\
\text { (including } \\
\text { switchers) }\end{array}$ & MATs & SATs \\
\hline \multirow[t]{2}{*}{$\mathrm{N}$ middle leaders } & $0.095^{* *}$ & 0.008 & $0.140 * *$ & 0.072 & -0.043 & $0.239 * *$ \\
\hline & $(2.244)$ & $(0.148)$ & $(2.076)$ & $(1.316)$ & $(-0.404)$ & (2.509) \\
\hline \multirow[t]{2}{*}{$\begin{array}{l}\mathrm{N} \text { deputy/assistant } \\
\text { heads }\end{array}$} & 0.097 & $0.415^{* * *}$ & 0.196 & 0.027 & -0.152 & $0.470^{* *}$ \\
\hline & $(1.074)$ & (3.193) & $(1.321)$ & $(0.238)$ & $(-0.800)$ & $(2.229)$ \\
\hline \multirow[t]{2}{*}{ Autonomy } & $0.628 * * *$ & $1.278^{* * *}$ & 2.585 & $0.828 * * *$ & & \\
\hline & $(2.995)$ & $(3.175)$ & $(0.317)$ & $(3.165)$ & & \\
\hline \multirow[t]{2}{*}{$\begin{array}{l}\text { Autonomy*middle } \\
\text { leaders }\end{array}$} & & $0.058^{* * *}$ & & & & \\
\hline & & $(2.829)$ & & & & \\
\hline \multirow[t]{2}{*}{$\begin{array}{l}\text { Autonomy*deputy/ } \\
\text { assistant heads }\end{array}$} & & $-0.178 * * *$ & & & & \\
\hline & & $(-3.468)$ & & & & \\
\hline R-squared & 0.560 & 0.561 & 0.563 & 0.562 & 0.624 & 0.544 \\
\hline $\mathrm{N}$ & 14,786 & 14,786 & 6,526 & 8,260 & 3,086 & 2,839 \\
\hline
\end{tabular}

Notes: t-statistics in parentheses. ${ }^{*} \mathrm{p}<0.10 ; * * \mathrm{p}<0.05 * * * \mathrm{p}<0.01$

Controls: prior average attainment at KS2; number of pupils in school; \% pupils eligible for FSM; \% pupils with English as an additional language; \% pupils with special educational needs; \% male pupils; \% pupils who are White British; dummy variable where any of pupil characteristics variables are missing; year. 
Table 9 KS4 GCSE points per entry, 2011-2016, regression results (fixed effects)

\begin{tabular}{|c|c|c|c|c|c|c|}
\hline & All & $\begin{array}{l}\text { All (plus } \\
\text { interaction) }\end{array}$ & Non-academies & \begin{tabular}{|l|} 
Academies \\
(including \\
switchers) \\
\end{tabular} & MATs & SATs \\
\hline \multirow[t]{2}{*}{$\mathrm{N}$ middle leaders } & 0.001 & -0.005 & -0.003 & 0.003 & 0.004 & 0.008 \\
\hline & $(0.279)$ & $(-1.224)$ & $(-0.573)$ & $(0.859)$ & (0.544) & (1.359) \\
\hline \multirow[t]{2}{*}{$\begin{array}{l}\mathrm{N} \text { deputy/assistant } \\
\text { heads }\end{array}$} & $0.022^{* * *}$ & $0.031 * * *$ & $0.034 * * *$ & $0.017 * *$ & 0.003 & $0.034 * *$ \\
\hline & (3.558) & (3.145) & (3.110) & $(2.155)$ & $(0.240)$ & $(2.486)$ \\
\hline \multirow[t]{2}{*}{ Autonomy } & 0.004 & 0.005 & 0.285 & 0.010 & & \\
\hline & $(0.246)$ & $(0.17)$ & $(0.766)$ & $(0.519)$ & & \\
\hline \multirow[t]{2}{*}{\begin{tabular}{|l|} 
Autonomy*middle \\
leaders
\end{tabular}} & & $0.003 * *$ & & & & \\
\hline & & $(2.175)$ & & & & \\
\hline \multirow[t]{2}{*}{\begin{tabular}{|l|} 
Autonomy*deputy/ \\
assistant heads \\
\end{tabular}} & & -0.004 & & & & \\
\hline & & $(-1.093)$ & & & & \\
\hline R-squared & 0.163 & 0.164 & 0.174 & 0.157 & 0.145 & 0.175 \\
\hline$N$ & 17,841 & 17,841 & 7,688 & 10,153 & 4,114 & 3,656 \\
\hline
\end{tabular}

Notes: t-statistics in parentheses. ${ }^{*} \mathrm{p}<0.10 ; * * \mathrm{p}<0.05 * * * \mathrm{p}<0.01$

Controls: prior average attainment at KS2; number of pupils in school; \% pupils eligible for FSM; \% pupils with English as an additional language; \% pupils with special educational needs; \% male pupils; \% pupils who are White British; dummy variable where any of pupil characteristics variables are missing; year. 
Appendix Table 1: Number of secondary schools by type, 2010/11-2015/16

\begin{tabular}{|l|r|r|r|r|r|r|}
\hline & $2010 / 11$ & $2011 / 12$ & $2012 / 13$ & $2013 / 14$ & $2014 / 15$ & $2015 / 16$ \\
\hline & & & & & & \\
\hline Community & 1,235 & 958 & 778 & 666 & 599 & 546 \\
\hline Foundation & 884 & 519 & 379 & 311 & 287 & 258 \\
\hline Voluntary aided & 483 & 397 & 338 & 313 & 285 & 271 \\
\hline Voluntary controlled & 78 & 62 & 43 & 40 & 34 & 35 \\
\hline Academy converter & 46 & 710 & 1,068 & 1,201 & 1,288 & 1,335 \\
\hline Academy sponsor led & 235 & 271 & 366 & 444 & 505 & 560 \\
\hline Free school & 0 & 5 & 30 & 66 & 98 & 111 \\
\hline Other & 3 & 5 & 13 & 35 & 58 & 72 \\
\hline & & & & & & \\
\hline All school types & 2,964 & 2,927 & 3,015 & 3,076 & 3,154 & 3,188 \\
\hline
\end{tabular}

